\title{
ANTIMICROBIAL ACTIVITIES OF SOLANUM INCANUM, ELETTARIA CARDAMOMUM AND ZINGIBER OFFICINALE, USED TRADITIONALLY TO TREAT PATHOGENIC MICROBES
}

\author{
E.A. Ewais ; Magda M. Aly ${ }^{* * * * *}$; M.A. Ismaill; E.H. Abdel Shakour ${ }^{*}$ and M.F. Hassanin ${ }^{*}$ \\ * Dept. Botany and Microbiology, Fac. Sci., Al-Azhar Univ., Cairo, Egypt. \\ ** Dept. Biology, Fac. Sci., King Abdulaziz Univ., Jeddah, Saudi Arabia. \\ *** Dept. Botany, Fac. Sci., Kafrelsheikh Univ., Egypt.
}

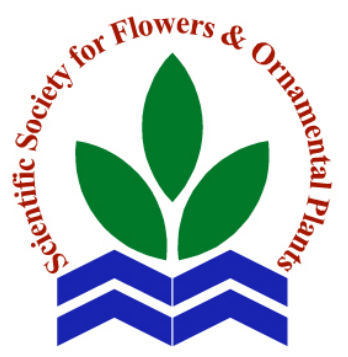

Scientific J. Flowers \& Ornamental Plants, 1(3):253-263 (2014).

Received:

9/11/2014

Revised by:

Prof. Dr. B.M. Refaat, Fac. Sci., Al-Azhar Univ.

Prof. Dr. E.S. Nofal, Kafr El-Sheikh Univ.

\begin{abstract}
The use and search for antibiotics derived from plants have been accelerated in recent years. Three plants, used traditionally as medicine and as food additives were collected and extracted with hot water, methanol, diethyl-ether, ethyl acetate and chloroform. The used plants were Solanum incanum, Elettaria cardamomum and Zingiber officinale. The plant extracts were screened for their inhibitory effects on eight bacterial and seven fungal pathogens using agar well diffusion method.
\end{abstract}

It was shown that methanol extract was more effective as compared to hot water, diethyl-ether, ethyl acetate and chloroform extracts. Inhibition zone diameters of the methanol extracts of the used plants ranged from 10 to $29 \mathrm{~mm}$ and minimum inhibitory concentrations (MIC) from 50 to $150 \mu \mathrm{g} / \mathrm{ml}$. No toxicity was found using Artimia salina as test organism. Antitumor activity against Ehrlich ascites carcinoma and Lymphoma cell line was recorded only for S. incanum extract.

Key words: Solanum incanum, Elettaria cardamomum, Zingiber officinale, antimicrobial activities, plant extracts.

\section{INTRODUCTION}

In recent times, there have been increases in antibiotic resistant strains of clinically important pathogens, which have led to the emergence of new bacterial strains that are multi-resistant (WHO, 1978; Aibinu et al., 2003 and Aibinu et al., 2004). Multiple drug resistance has developed due to the indiscriminate use of commercial antimicrobial drugs commonly used in the treatment of infectious disease (Davis, 1995). The increasing prevalence of multidrug resistant strains of bacteria and the recent appearance of strains with reduced susceptibility to antibiotics raises the specter of untreatable bacterial infections and adds urgency to the search for new infectionfighting strategies (Sieradzki et al., 1999). Such a fact is cause for concern, because of the number of patients in hospitals who have suppressed immunity, and due to new bacterial strains, which are multi-resistant. Consequently, new infections can occur in hospitals resulting in high mortality. The indiscriminate use of antibiotics has led to drug resistance of many bacterial strains. The development of multidrug-resistant pathogens has been related to the occurrence of over and under-dosage of antimicrobials (Vargas et al., 2004; Schelz et al., 2006). The emergency of antibiotic resistance by bacteria has become a medical catastrophe and we may be entering a 'post-antibiotic' era where antibiotics are no longer effective. Development of new microbial compounds for resistant organisms is becoming critically important (Martini and Eloff, 1998). Herbal medicine is the oldest and most tried and tested form of medicine. In a sense it forms the basis of all medicine. It is the original 


\section{E.E.A. Ewais et al.}

medicine, the mother of all remedies used today. It has been used by all cultures for centuries and is still the main form of medical treatment. Herbal medicine is the most important medicine for the majority of people on the planet, especially those who cannot afford expensive drugs (McKenna, 1996). Solanum incanum, commonly known as bitter garden egg belongs to the family Solanaceae. It is a delicate perennial often cultivated as an annual crop. It is a shrub, growing 1-3 $\mathrm{m}$ high. The leaves are simple, ovate, elliptic, $2.5-12 \mathrm{~cm}$ long and $2.5-8 \mathrm{~cm}$ wide. The fruit is fleshy, less than $3 \mathrm{~cm}$ in diameter on wild plants but much larger in cultivated forms. Fruit is spherical, green, often striped with white, turning yellow to orange-brown when ripe (Denston, 1951). Solanum species are the most potent plants against pathogenic microorganisms. Solanum incanum (L) is one of the important traditional medicinal plants belongs to Solanacae family. Antibacterial activity of Solanum incanum was studied (Britto and Senthilkumar, 2001 and Pavitra et al., 2012) and presence of analysis of phytochemicals were also studied (Pavitra et al., 2012). Other Solanum species, S. torvum (leaf, stem and roots) showed antibacterial and antifungal activity (Bari et al., 2010) and antibacterial activity of Solanum surattense whole plant extract (Patil et al., 2009) and leaf extract (Sheeba, 2010) were studied. Analysis, presence of phytochemicals and potent antibacterial activity of leaf, root and seed extracts were studied in S. nigrum (Sridhar et al., 2011). Cardamom is a dried fruit of Elettaria cardamomum belonging to family Zingiberaceae. It is commonly known as queen of spices for the versatile use in culinary practice. Cardamom is a perennial shrub with thick, fleshy, lateral roots which can grow to a height of eight feet (Kapoor, 2000). Soriful et al. (2010) studied the antimicrobial activity of Elettaria cardamomum on some Gram positive bacteria: Staphylococcus aureus, Bacillus subtilis, Bacillus megaterium, and Sarcina lutea as well as Gram negative bacteria: Klebsiella pneumoniae, Pseudomonas aeruginosa, Salmonella typhi, Shigella dysenteriae, and Shigella sonnei. Methanolic extract inhibited the growth of all the tested bacteria having various degrees of inhibition zones. Ginger known as rhizomes of Zingiber officinale (Zingiberaceae) is one of the spices valued for its aroma and pungency characteristic. It grows in the tropical region, especially in the southern and eastern part of Asia. That spice is commercialized in the dry form. Ginger is a stimulant, carminative and frequently used for dyspepsia, gastroparesis, constipation and colic (Wood, 2013). Ginger oil has been proved to prevent skin cancer in mice (Oyagbemi et al., 2010). Some studies have demonstrated that gingerols can be used to fight against ovarian cancer (Park et al, 2008; McGee, 2004). [10]-gingerol and [12]gingerol isolated from ginger rhizome have been reported to show antibacterial activity against periodontal bacteria (Bartley and Jacobs, 2000). Previous phytochemical investigations on the rhizome of Zingiber officinale yielded 6-gingerol, zingerone, shogaol, butyl hydroxyl toluene, butyl hydroxyl anisole (Imadia et al., 1983; Miri et al., 2008). The aim of the present study was detection of antimicrobial activities and toxicity of Solanum incanum, Elettaria cardamomum and Zingiber officinale.

\section{MATERIALS AND METHODS}

\section{Plant materials:}

Aerial parts, fruits, roots and leaves of some plants were collected from local markets in Jeddah, Saudi Arabia during summer 2012. The collected plant materials were put in clean plastic bags and transferred directly to the lab. The plants under investigation were Solanum incanum, Elettaria cardamomum and Zingiber officinale (the families and common names of these plants are shown in Table, 1).

\section{Tested organisms:}

Bacterial and fungal isolates were obtained from Biology Department, Faculty of Science, King Abdul-Aziz University (KAU), Jeddah, Saudi Arabia. The bacterial strains were Escherichia. coli ATCC 25922, 
Table 1. The selected medicinal plants, their families and common names.

\begin{tabular}{llll}
\hline Scientific name & Family & Common name & Used part \\
\hline Solanum incanum & Solanaceae & Bitter apple & fruits \\
Zingiber officinale & Zingiberaceae & Ginger & Root \\
Elettaria cardamomum & Zingiberaceae & Cardamom & fruits \\
\hline
\end{tabular}

Pseudomonas aeruginosa ATCC 27853, Klebsiella pneumoniae (ESBL) ATCC 700603 , A. baumannii ATCC 1656-2, P. mirabilis ATCC 12453, Staphylococcus aureus ATCC 25923, Staphylococcus aureus (MRSA) ATCC 33591, and Enterococcus faecalis (VRE) ATCC 51299. The tested fungi were Aspergillus flavus, Aspergillus niger, Epidermophyton floccosum, Trycophyton mentagrophytes and Microsporum canis. Two strains of yeast have been investigated in this study; Candida albicans and Cryptococcus neoformans.

\section{Preparation of plant extracts:}

Organic solvents used in this experiment were obtained from Sigma-Aldrich Company. The dried roots, seeds or leaves were ground into fine powder with an electric blender. Fifty grams were suspended in hot water or organic solvents (methanol, diethyl-ether, ethyl acetate and chloroform) in sterile $250 \mathrm{ml}$ conical flasks and kept at $4^{\circ} \mathrm{C}$ overnight. After overnight incubation, the supernatant was filtered through Whatman No.1 filter paper and the filtrate was concentrated by evaporation in a rotary evaporator at $40^{\circ} \mathrm{C}$. The residue was weighed, dissolved in 5\% dimethyl sulfoxide (DMSO) and stored in the refrigerator at $4^{\circ} \mathrm{C}$ prior to use.

\section{Antimicrobial activity:}

This test was carried out using agar well diffusion method according to Joshi et al. (2009). Bacteria or yeast were taken and shaken in the sterile distilled water corresponding to $10^{8} \mathrm{CFU} / \mathrm{ml}$ for bacteria and $10^{6} \mathrm{CFU} / \mathrm{ml}$ of yeast (Mihajilov-Krstev et al., 2010). Fungal inocula were prepared by flooding Petri dish with 8 to $10 \mathrm{ml}$ of distilled water and the conidia were scraped using sterile spatula. The spore density of each fungus was $1.5 \times 10^{4}$ spore $/ \mathrm{ml}$ (Adigüzel et al., 2005). Minimal inhibitory concentration was determined by the method recommended by Ter-Laak et al. (1991). Each antimicrobial agent was serially diluted by transferring $100 \mu \mathrm{l}$ of the antimicrobial agent through sterilized microtitre plate containing $100 \mu \mathrm{l}$ media (nutrient broth for bacteria, Sabouraud dextrose broth for fungi and yeast). Freshly prepared standard number of cells $\left(1.5 \times 10^{8} \mathrm{CFU} / \mathrm{ml}\right.$ for bacteria or yeast and $4 \times 10^{4}$ spore $/ \mathrm{ml}$ for fungal isolates) was added to the media that contained some drops of phenol red. Glucose metabolisms were measured by a change of the color of phenol red indicator from red to yellow. MIC was determined at the concentration with no color change and DMSO was used as a control.

\section{Toxicity and antitumor activity of the plant extracts:}

Cytotoxicity is performed by Brine Shrimp Test (BST). Different dilutions of each plant extract made in DMSO were prepared $(100,200,300$ and $400 \mu \mathrm{g} / \mathrm{ml})$ and $0.5 \mathrm{ml}$ of each dilution was added to $4.5 \mathrm{ml}$ of brine solution and maintained at room temperature for $24 \mathrm{~h}$ under the light (Krishnaraju et al., 2005). The surviving larvae were counted by light microscope and the number of dead shrimps in each vial was recorded. The concentration at which $50 \%$ of the larvae were killed $\left(\mathrm{LD}_{50}\right)$ was determined as the toxic concentration (Lachumy et al., 2010). The antitumor activity of the tested plants was determined against Ehrlich carcinoma and Lymphoma cell line. Cells 


\section{E.E.A. Ewais et al.}

were grown in RPMI 1640 medium (Sigma, USA) with $10 \%$ fetal calf serum (FCS) (Gibco, USA) at $37^{\circ} \mathrm{C}$ under a humidified atmosphere consisting of $95 \%$ air and $5 \%$ $\mathrm{CO} 2$ for $48 \mathrm{~h}$. The percentage of cell viability was assessed to determine the $50 \%$ lethal dose by which $50 \%$ of cells are killed $\left(\mathrm{LD}_{50}\right)$.

\section{RESULTS AND DISCUSSION}

The non-availability and high cost of new generation antibiotics with limited effective span have resulted in increase in morbidity and mortality (Williams, 2000). Therefore, there is a need to look for substances from other sources with proven antimicrobial activity. Consequently, this has led to the search for more effective antimicrobial agents among materials of plant origin, with the aim of discovering potentially useful active ingredients that can serve as source and template for the synthesis of new antimicrobial drugs (Pretorius et al., 2003).

In this study, three plants were collected and extracted using hot water, methanol, ethyl acetate, N-butanol, diethyl ether and chloroform. The tested plants were $S$. incanum, E. cardamomum and Z. officinale.

The tested plants were selected based on traditional medicine knowledge used by Saudi Arabian people. All the obtained extracts were screened for their antibacterial activity against $E$. coli.

It was clear that all of the extracts have inhibitory activity against $E$. coli (Table, 2). The inhibitory activity varied according to the solvent used. The methanol extracts for all of tested plants showed significant antibacterial activities against $E$. coli compared to the activity of the other solvents which almost have similar effect. Previous studies provide similar results for methanol as a better solvent for more consistent extraction of antimicrobial substances from medicinal plants as compared to other solvents such as water and ethanol (Ahmad et al., 1998), hot water, N- butanol, diethyl- ether, ethyl acetate and chloroform (E1 Sayed and Aly, 2014).

Since methanol extract was the most active solvent, its activity was tested against the other pathogenic organisms including Gram positive bacteria ( $S$. aureus, $S$. aureus MRSA and E. faecalis VRE), Gram negative bacteria ( $P$. aeruginosa, K. pneumonia, $A$. baumannii and $P$. mirabils ), yeast ( $C$. albicans, and $C$. neoformans) and molds ( $A$. flavus, $A$. niger, $E$. floccosum.,T. mentagrophytes and M. canis) ( Tables, 3 and 4).

S. incanum has an effect on Gram negative and Gram positive isolates, but zones of inhibition are greater in Gram negative organisms $(17-29 \mathrm{~mm}$.). It has the best activity against $P$. aeruginosa. MIC values were $50-150 \mu \mathrm{g} / \mathrm{ml}$. The most affected Gram negative organism was $E$. coli, while E. faecalis was the most resistant organism.

In accordance, Omwenga et al. (2012) found that the methanolic extract of $S$. incanum has better activity on $P$. aeruginosa producing a wide zone of inhibition compared to $S$. aureus and B. subtilis. Such results are promising since $P$. aeruginosa is hard to be controlled by most antibiotics due to its cell wall properties (Omwenga et al., 2009).

$Z$. officinale is exceeding the effect of $S$. incanum against Gram negative bacteria (inhibition zones, 22-24 mm., MIC 50-100 $\mu \mathrm{g} / \mathrm{ml}$.). Significant antimicrobial activity of $Z$. officinale against $E$. coli has been reported by Yahaya et al. (2012). Gull et al. (2012) reported antimicrobial activity of the plant methanolic extract on both Gram positive and Gram negative bacteria. The antibacterial activities of the extracts are expected perhaps due to the compounds like flavonoids and volatile oil which were dissolved in organic solvents. It is reported that sesquiterpenoids are the main component of ginger which attributes its antibacterial activity (Malu et al., 2008). 
Table 2. The antibacterial activity of some plants extracts using water and organic solvents against $E$. coli.

\begin{tabular}{lcccccc}
\hline & \multicolumn{5}{c}{ Diameter of inhibition zone mm } \\
Plant & Hot water & Methanol & N- butanol & $\begin{array}{c}\text { Diethyl- } \\
\text { ether }\end{array}$ & Ethyl acetate & Chloroform \\
\hline S. incanum & $19 \pm 0.07$ & $39 \pm 1.0$ & $19 \pm 0.9$ & $17 \pm 0.2$ & $15 \pm 0.9$ & $18 \pm 0.4$ \\
Z. officinale & $18 \pm 0.17$ & $39 \pm 1.0$ & $19 \pm 0.6$ & $17 \pm 0.2$ & $15 \pm 1.0$ & $18 \pm 2.0$ \\
E. cardamomum & $17 \pm 1.30$ & $26 \pm 1.0$ & $18 \pm 0.3$ & $17 \pm 0.4$ & $19 \pm 2.0$ & $13 \pm 1.0$ \\
Bacterial index $^{*}$ & 54 & 104 & 56 & 51 & 49 & 49 \\
\hline
\end{tabular}

* Bacterial Index: Total Activity (mm).

Table 3. Antibacterial Activities (Diameter of the Inhibition Zone, mm) of the methanolic plant extracts against different pathogenic bacteria.

\begin{tabular}{lcccc}
\hline Bacteria & S. incanum & E. cardamomum & Z. officinale & $\begin{array}{c}\text { Control } \\
\text { (DMSO) }\end{array}$ \\
\hline P. aerugenosa & $29 \pm 1.0$ & $27 \pm 0.2$ & $23 \pm 3.0$ & ND \\
K. pneumoniae & $16 \pm 1.0$ & $16 \pm 0.2$ & $22 \pm 2.8$ & ND \\
P. mirabilis & $17 \pm 2.1$ & $16 \pm 0.4$ & $24 \pm 0.5$ & ND \\
A. baumannii & $19 \pm 0.8$ & $26 \pm 0.4$ & $12 \pm 0.6$ & ND \\
E. faecalis & $11 \pm 0.5$ & $14 \pm 0.6$ & $11 \pm 0.4$ & ND \\
S. aureus 33591 & $14 \pm 0.9$ & $12 \pm 0.4$ & $18 \pm 0.4$ & ND \\
S. aureus 25923 & $14 \pm 1.0$ & $18 \pm 0.8$ & $14 \pm 0.8$ & ND \\
Bacterial index & 120 & 129 & 124 & ND \\
\hline
\end{tabular}

*Bacterial Index: Total Activity (mm).

Table 4. The minimal inhibitory concentration $(\mu \mathrm{g} / \mathrm{ml})$ of methanolic extracts against different pathogenic bacteria.

\begin{tabular}{|c|c|c|c|c|}
\hline Bacteria $\quad$ Plants & S. incanum & E. cardamomum & Z. officinale & $\begin{array}{l}\text { Control } \\
\text { (DMSO) }\end{array}$ \\
\hline P. aerugenosa & 50 & 50 & 100 & $>200$ \\
\hline K. pneumoniae & 150 & 150 & 50 & $>200$ \\
\hline P. mirabilis & 150 & 100 & 50 & $>200$ \\
\hline A. baumannii & 150 & 50 & 150 & $>200$ \\
\hline E. faecalis & 150 & 150 & 150 & $>200$ \\
\hline S. aureus 33591 & 100 & 150 & 100 & $>200$ \\
\hline S. aureus 25923 & 100 & 100 & 100 & $>200$ \\
\hline E. coli & 100 & 50 & 100 & $>200$ \\
\hline
\end{tabular}




\section{E.E.A. Ewais et al.}

The greater antimicrobial activity for the methanolic extracts of the three tested plants was E. cardamomum. It has relative increasing in inhibition zones compared to $Z$. officinale with exception of $K$. pneumonia, $P$. mirabilis and $S$. aureus 33591 as Zingiber officinale had a stronger effect.

The inhibitory effect on Gram negative strains was greater than Gram positives. The markedly increase in the antimicrobial activity against $P$. aeruginosa, Gram negative bacteria and $E$. faecalis (VRE) among Gram positive bacteria is contributing to the production of drugs effective against multi-drug resistant bacteria. In accordance, Jemal et al. (2011) observed that complete $(100 \%)$ growth inhibition was at $15 \%$ cardamom hydrosol concentration against $E$. coli, $S$. aureus and $S$. typhi, but in contrast, he found $P$. aeruginosa as the most resistant organism.

Antifungal activity of the selected plants has also been investigated and represented in Tables (5) and (6). E. cardamomum had the highest values of inhibition on filamentous fungi with exception of $A$. niger compared to methanolic extracts of other plants. $S$. incanum has the highest effect on such strain. Inhibition zones of E. cardamomum ranged from 11 to $17 \mathrm{~mm}$, the former was recorded for $A$. niger. MIC were 50-100 $\mu \mathrm{g} / \mathrm{ml}$. Obvious antimicrobial action on dermatophytes (E. floccosum, $T$. mentagrophytes and M. canis) was observed. It also recorded considerable effect against C. albicans. A similar result was obtained by Ağaoğlu et al. (2005). According to Aneja and Sharma (2010), E. cardamomum displayed good to moderate activity against C. albicans. E. cardamomum is widely used in various parts of the world's traditional medicine system and it has been used in India since ancient times (Dhulap et al., 2008). The antimicrobial potential of this plant extracted in different solvents (e.g. aqueous, methanol, ethanol, acetone, chloroform, hexane, ethyl acetate and diethyl ether) had been evaluated against different bacterial and fungal human pathogens and had reported variable activities in different parts, seeds, pods and fruits in different solvents (Dhulap et al., 2008; Agaoglu et al., 2005; Kaushik et al., 2010; Singh et al., 2008 and Aneja and Joshi, 2009).

Cytotoxic effect using brine shrimp and antitumor activity using Erlich cell line and lymphoma cell line of the plants under investigation were studied and represented in Table (7). The highest cytotoxic effect was recorded for the methanolic extract of $S$. incanum $\left(\mathrm{LD}_{50}\right.$ is 600$)$, while the minimal effect was recorded for E. cardamomum $\left(\mathrm{LD}_{50}\right.$ is $\left.\geq 600\right)$. Antitumor activity of $E$. cardamomum, and $Z$. officinale showed $\mathrm{LD}_{50}$ $\geq 600 \mu \mathrm{g} / \mathrm{ml}$ on both Lymphoma cell line and Erlich cell line, while it was $400 \mu \mathrm{g} / \mathrm{ml}$ on $S$. incanum $\mu \mathrm{g} / \mathrm{ml}$ on both Erlich cell line and lymphoma cell line.

\section{CONCLUSION}

On the basis of the experimental results and discussion, it can be postulated that methanol is the best solvent for all of the plants under investigation. S. incanum and $Z$. officinale methanolic extracts can be used effectively against $E$. coli. Moreover, $S$. incanum was the best plant extract against $P$. aeruginosa. Methanolic extract of $Z$. officinale provides the best action against $S$. aureus (MRSA) and K. pneumonia (ESBL). So, it is considered to be as promising antibiotic against multidrug resistant bacteria. E. cardamomum has broad spectrum antimicrobial activity against Gram negative bacteria, Gram positive bacteria, yeast and filamentous fungi.

\section{REFERENCES}

Adigüzel, A.; Güllüce, M.; Şenqül, M.; Öğütcü, H.; Şahian, F. and Karaman, I. (2005) Antimicrobial effects of Ocimum basilicum (Labiatae) extract, Turkish J. Biotechnol., 29:155-160.

Agaoglu, S.; Dostbil, N. and Alemdar, S. (2005). Antimicrobial effect of seed extract of Cardamom (Elettarla cardamomum Maton). YYU Vet. Fak. Derg., 16(2):99-101. 
Table 5. Effect of the methanolic extracts on fungi and yeast.

\begin{tabular}{|c|c|c|c|c|}
\hline $\begin{array}{ll}\text { Fungi } & \text { Plants } \\
\end{array}$ & S. incanum & E. .cardamomum & Z. officinale & $\begin{array}{r}\text { Control } \\
\text { (DMSO) } \\
\end{array}$ \\
\hline A. flavus & $11 \pm 1.0$ & $17 \pm 0.23$ & $13 \pm 1.3$ & ND \\
\hline A. niger & $17 \pm 0.8$ & $11 \pm 0.08$ & $10 \pm 0.5$ & ND \\
\hline E. floccosum & $11 \pm 1.2$ & $14 \pm 0.22$ & $11 \pm 0.8$ & ND \\
\hline T. mentagrophytes & $11 \pm 1.1$ & $13 \pm 0.43$ & $11 \pm 1.5$ & ND \\
\hline M. canis & $11 \pm 0.18$ & $16 \pm 0.14$ & $11 \pm 0.16$ & ND \\
\hline C. albicans & $10 \pm 0.15$ & $16 \pm 0.16$ & $11 \pm 0.10$ & ND \\
\hline C. neoformans & $13 \pm 1.4$ & $11 \pm 0.8$ & $13 \pm 0.18$ & ND \\
\hline Fungal index ${ }^{*}$ & 84 & 98 & 80 & ND \\
\hline
\end{tabular}

*Fungal Index: Total Activity (mm).

Table 6. The minimal inhibitory concentration $(\mu \mathrm{g} / \mathrm{ml})$ of methanolic extracts against different pathogenic fungi and yeast, compared with that of control.

\begin{tabular}{|c|c|c|c|c|}
\hline $\begin{array}{ll}\text { Fungi } & \text { Plants } \\
\end{array}$ & S. incanum & E. cardamomum & Z. officinale & $\begin{array}{l}\text { Control } \\
\text { (DMSO) }\end{array}$ \\
\hline A. flavus & 50 & 100 & 100 & $>200$ \\
\hline A. niger & 50 & 100 & 100 & $>200$ \\
\hline E. floccosum & 100 & 100 & 50 & $>200$ \\
\hline T. mentagrophytes & 100 & 50 & 50 & $>200$ \\
\hline M. canis & 50 & 100 & 50 & $>200$ \\
\hline C. albicans & 50 & 50 & 100 & $>200$ \\
\hline C. neoformans & 150 & 150 & 150 & $>200$ \\
\hline
\end{tabular}

Table 7. Toxicity against Artimia salina (\% mortality) and antitumor activities of the different concentrations of plant methanolic extracts.

\begin{tabular}{|c|c|c|c|c|c|c|c|}
\hline \multirow[b]{2}{*}{ Plants } & \multicolumn{5}{|c|}{$\begin{array}{c}\text { Toxicity against Artimia salina }(\% \text { of mortality) at different } \\
\text { concentrations }(\mu \mathrm{g} / \mathrm{ml})\end{array}$} & \multicolumn{2}{|c|}{$\begin{array}{l}\text { Antitumor activity }\left(\mathrm{LD}_{\mathbf{5 0}},\right. \\
\boldsymbol{\mu \mathrm { g } / \mathrm { ml } )}\end{array}$} \\
\hline & Control & 200 & 400 & 600 & $\mathbf{L D}_{50}$ & $\begin{array}{l}\text { Lymphoma } \\
\text { cell line }\end{array}$ & $\begin{array}{l}\text { Erlich cell } \\
\text { line }\end{array}$ \\
\hline S. incanum & 0 & 10 & 20 & 59 & 500 & 400 & 400 \\
\hline E. cardamomum & 0 & 0 & 0 & 10 & $\geq 600$ & $\geq 600$ & $\geq 600$ \\
\hline Z. officinale & 0 & 0 & 10 & 26 & $\geq 600$ & $\geq 600$ & $\geq 600$ \\
\hline
\end{tabular}




\section{E.E.A. Ewais et al.}

Ahmad, I.; Mehmood, Z. and Mohammad, F. (1998). Screening of some Indian medicinal plants for their antimicrobial properties. Journal of Ethnopharmacology, 62(2):183-193.

Aibinu, I.; Adenipekun, E.; and Odugbemi, T. (2004). Emergence of quinolone resistance amongst Escherichia coli strains isolated from clinical infections in some Lagos State Hospitals in Nigeria. Nigerian Journal of Health and Biomedical Science, 3(2):73-78.

Aibinu, I.E.; Ohaegbulam, V.C.; Adenipekun, E.A.; Ogunsola, F.T.; Odugbemi, T.O. and Mee, B.J. (2003). Extended-spectrum beta-lactamase enzymes in clinical isolates of Enterobacter species from Lagos, Nigeria. Journal of Clinical Microbiology. 41(5):2197-2200.

Aneja, K.R. and Radhika, J. (2009). Antimicrobial activity of Amomum subulatum and Elettaria cardamomum against dental caries causing microorganisms. Ethnobotanical Leaflets, 13:840-49.

Aneja, K.R. and Chetan, S. (2010). Antimicrobial potential of fruit extracts of Elettaria cardamomum Maton (CHHOTI ELAICHI) against the pathogens causing ear infection. Pharmacologyonline 3: 750-756.

Bari, M.A.; Islam, W.; Khan, A.R. and Abul, M. (2010). Antibacterial and antifungal activity of Solanum torvum (Solanaceae). International Journal of Agricultural journal, 12(3): 386-390.

Bartley, J. and Jacobs, A. (2000). Effect of drying on flavor compounds in Australian-grown ginger (Zingiber officinale). Journal of the Science of Food and Agriculture, 80:209-215.

Britto, S.J. and Senthinkumar, S. (2001). Antimicrobial activities of Solanum incanum leaf extract. Asian J. Microbiol., Biotechnol. and Environ. Sci., 3(1-2):6566.
Davis, J. (1995). Inactivation of the antibiotics and the dissemination of resistance genes. Science, 264:375-382). (Service RF, Antibiotics that resist resistance. Science 270: 724-727).

Denston, T.C. (1951). A Textbook of Pharmacology, $5^{\text {th }}$ edition, Medicinal Plants of West Africa. London Oxford Press, 147-149.

Dhulap, S; Anita, M. and Hirwani, R.R. (2008). Phyto-pharmacology of Elettaria cardamomum. Phcog Rev Sup 2(4):2735 .

El-Sayed, H. and Aly, M. (2014). Antibacterial activities of six medicinal plants used traditionally by Saudi people to treat common diseases. British Biotechnology Journal, 4(4):499-510.

Gull, I.; Mariam, S.; Halima, S.; Shahbaz, M. Aslam; Zahoor, Q. Samra and Amin, M. Athar (2012). Inhibitory effect of Allium sativum and Zingiber officinale extracts on clinically important drug resistant pathogenic bacteria. Annals of Clinical Microbiology and Antimicrobials, 11:8-22.

Imadia, K.; Fukushima, S.; Shirai, T.; Ohtani, M.; Nakanish, K. and Ito, N. (1983). Promoting activities of butylated hydroxytoluene on 2-stage urinary bladed carcinogenesis and inhibition of $\gamma$ glutamyl transpeptidase development in the liver of rats. Carcinogenesis, 4:895899.

Jemal, H.; Chalachew, T. and Jemal, M. (2011). Assessment of the antimicrobial effects of some ethiopian aromatic spice and herb hydrosols. International Journal of Pharmacology, 7(5):635-640.

Joshi, B.; Lekhak, S. and Sharma, A. (2009): Antibacterial property of different medicinal plants: Ocimum sanctum, Cinnamomum zeylanicum, Xanthoxylum armatum and Origanum majorana. Journal of Science, Engineering and Technolgy, 5 (I): 143- 150. 
Kapoor, L.D. (2000). Handbook of Ayurvedic Medicinal Plants. CRC Press, Boca Raton, FL, 424 pp.

Kaushik, P.; Goyal, P.; Chauhan, A. and Chauhan, G. (2010). In Vitro evaluation of antibacterial potential of dry fruit extracts of Elettaria cardamomum Maton (Chhoti Elaichi). Iranian J Pharm Res, 9(3):287-292.

Krishnaraju, A.V.; Rao, T.V.N.; Sundararaju, D.; Vanisree, M.; Tsay, H. and Subbaraju, G.V. (2005). Assessment of bioactivity of Indian medicinal plants using brine shrimp (Artemia salina) lethality assay. International Journal of Applied Science and Engineering, 3(2):125-134.

Lachumy, S.J.; Zuraini, Z. and Sasidharan, S. (2010). Antimicrobial activity and toxicity of methanol extract of Cassia fistula seeds. Research Journal of Pharmaceutical, Biological and Chemical Sciences, 1(4):391- 398.

Malu, S.P.; Obochi, G.O.; Tawo, E.N. and Nyong, B.E. (2008). Antibacterial activity and medicinal properties of ginger (Zingiber officinale). Global $\mathrm{J}$. Pure. Appl. Sci., 15:365-368.

Martini, N. and Eloff, J.N. (1998). The preliminary isolation of several antibacterial compounds from Combretum erythrophyllum (Combretaceae). Journal of Ethnopharmacology, 62:255-2643.

McGee, H. (2004). On Food and Cooking: The Science and Lore Of The Kitchen $\left(2^{\text {nd }}\right.$ ed. $)$. New York: Scribner, 425-426.

McKenna, J. (1996). Alternatives to Antibiotics. Gill \& Macmillan Ltd., Golden bridge, Dublin, 55-58.

Mihajilov-Krstev, T.; Radnović, D. and Kitić, D. (2010). Antimicrobial activity of Satureja L. essential oils against phytopathogenic bacteria Erwinia amylovora. Biologica Nyssana., 1(12):95-98.
Miri. P.; Jungdon, B. and Dae-Sil, L. (2008). Antibacterial activity of [10]-gingerol and [12]-gingerol isolated from ginger rhizome against periodontal bacteria. Phytotherapy Research, 22(11):14461449.

Omwenga, E.O.; Ogol, C.; Paul, K.M. and Paul, O.O. (2012). Ethnobotanical identification and anti-microbial evaluation of some anti-diarrhoreal plants used by the Samburu Community, Kenya. Malaysian Journal of Microbiology, 8(2):68-74.

Omwenga, E.O.; Okemo, P.O.; Mbugua, P.K. and Ogol, C.K.P (2009). Ethnobotanical survey and the antimicrobial evaluation of medicinal plants used by the Samburu community (Kenya) for treatment of diarrhorea. Pharmacognosy Magazine, 4(18):165176.

Oyagbemi, A.A.; Saba, A.B. and Azeez, O.I. (2010). Molecular targets of [6]-gingerol: Its potential roles in cancer chemoprevention. Biofactors, 36(3):169178.

Park, M.; Bae, J. and Lee, D. (2008). Antibacterial activity of [10]-gingerol and [12]-gingerol isolated from ginger rhizome against periodontal bacteria. Phytother. Res., 22:1446-1449.

Patil, S.; Joshi, V.; Sutar, P. and Sambrekar, S. (2009). Screening of whole plant extract of Solanum surattense for antibacterial activity. International Journal of Pharmaceutical Sciences, 1(1):110-114.

Pavitra P.S.; Janani, V.S.; Charumathi, K.H.; Indumathy, R.; Sirisha, P. and Rama, S.V. (2012). Antibacterial activity of plants used in Indian herbal medicine. International Journal of Green Pharmacy, $4(1): 22-28$.

Pretorius, J.C.; Magama, S. and Zietsman, P.C. (2003). Growth inhibition of plant pathogenic bacteria and fungi by extracts from selected South African plant 


\section{E.E.A. Ewais et al.}

species. South African Journal of Botany, 20:188-192.

Schelz, Z.; Molnar, J. and Hohmann, J. (2006). Antimicrobial and antiplasmid activities of essential oils. Fitoterapia.,77(4):279-85.

Sheeba, E. (2010). Antibacterial activity of Solanum surattense Burm. F. Kathamandu University Journal of Science, Engineering and Technology. 6(1):1-4.

Sieradzki, K.; Roberts, R.B.; Haber, S.W. and Tomasz, A. (1999). The development of vancomycin resistance in a patient with methicillin-resistant Staphylococcus aureus infection. N. Engl. J. Med., 340:517-523.

Singh, G.; Kiran, S.; Marimuthu, P.; Isidorov, V. and Vinogorova, V. (2008). Antioxidant and antimicrobial activities of essential oil and various oleoresins of Elettaria cardamomum (seeds and pods).

J. Sci. Food Agric., 88:280-289.

Soriful, I.; Atikur, R.; Mominul, I.S.; Mostafizur, R.; Abu Hena, M.J. and Firoz, A. (2010). In vitro antibacterial activity of methanol seed extract of Elettaria cardamomum (L.) Maton. Agriculturae Conspectus Scientificus., 75(3):113-117.

Sridhar, T.M.; Josthna, P.; and Naidu, C.V. (2011). In vitro Antibacterial activity and phytochemical analysis of Solanum nigrum (Linn.) - An important antiulcer medicinal plant. Journal of Experimental Sciences, 2(8):24-29.

Ter-Laak, E.A.; Pijpers, A.; Noordergraaf, J.H.; Schoevers, E.C. and Verheijden, J.H. (1991). Comparison of methods for in vitro testing of susceptibility of porcine Mycoplasma species to antimicrobial agents. Antimicrob Agents Chemother 35:228-233.

Vargas, A.C.; Loguercio, A.P.; Witt, N.M.; Costa, M.M.; Silva, M.S. and Viana, L.R. (2004). Alcoholic propolis extract: antimicrobial activity. Cienc. Rural., 34(1):159-63.

Williams, R. (2000). Antimicrobial resistance a global threat. Essential Drug Monitor, 1:28-29

Wood, G.B. (2013). A treatise on therapeutics, and pharmacology or materia medica: Volume 2. J. B. Lippincott \& Co. 1867a. Retrieved 2 March; 2013.

World Health Organization (1978). The promotion and development of traditional medicine. Technical Report Series, 622 pp.

Yahaya, O.; Yabefa, J.A.; Umar, I.O.; Datshen, M.M.; Egbunu, Z.K. and Ameh, J. (2012). Combine antimicrobial effect of ginger and honey on some human pathogens. British Journal of Pharmacology and Toxicology, 3(5):237239.

\footnotetext{
النشاط الضد ميكروبي لنباتات الحنظل و الهيل و الزنجبيل المستخدمة عادة في علاج

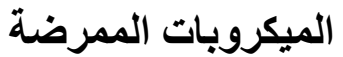

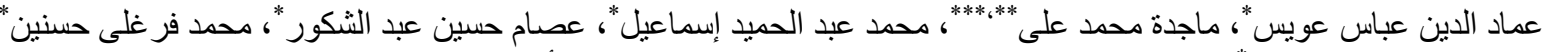

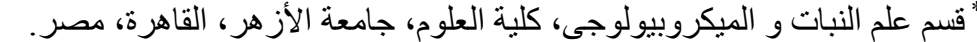

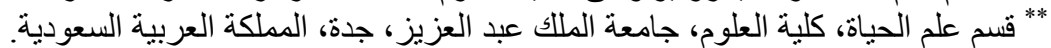

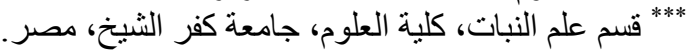

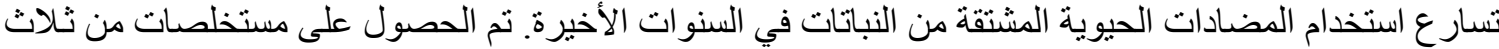

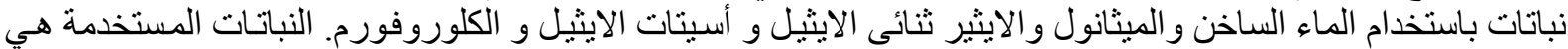
الحنظل (Solanum incanum) و الهيل (Elettaria cardamomum) و الزنجبيل (Zingiber officinale). و قد تم

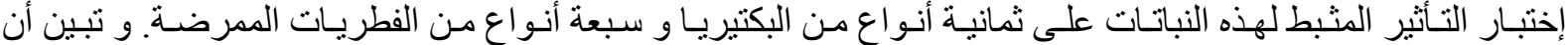

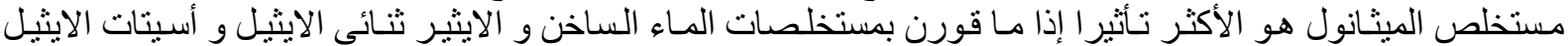




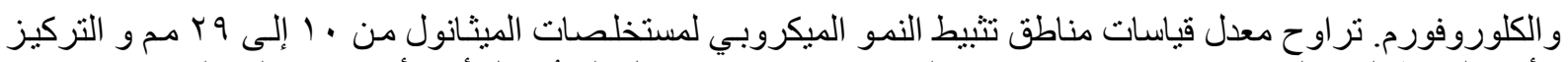

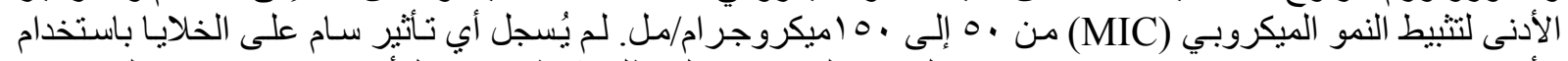

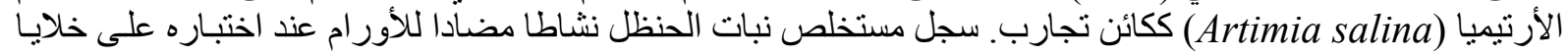

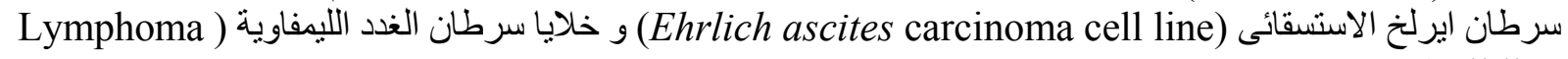
(cell line 
